Niniejsza publikacja jest dostęna na licencji Creative Commons. Uznanie autorstwa-Użycie niekomercyjne-Bez utworów zależnych 3.0 Polska. Pewne prawa zastrzeżone na rzecz autora. Zezwala się na wykorzystanie publikacji zgodnie z licencja - pod warunkiem zachowania niniejszej informacji licencyjnej oraz wskazania autora jako właściciela praw do tekstu. Treść licencji jest dostępna na stronie: http://creativecommons.org/licenses/by-nc-nd/3.0/pl/

Lingwistyka Stosowana 23: 3/2017, 15-25

\author{
Jarochna DĄBROWSKA-BURKHARDT \\ Uniwersytet Zielonogórski
}

\title{
O języku niemieckim w Polsce. Stereotypy i wyobrażenia na przestrzeni wieków.
}

\begin{abstract}
:
German language in Poland. Stereotypes and notions throughout the centuries.

This paper addresses the image of the German language, which has been firmly established throughout the centuries in the Polish culture and verification of its image given on the grounds of a questionnaire among German language students at the University of Zielona Góra. Perceptions about stereotypes are inextricably linked with perception of their speakers. For this reason, the German language is viewed through the prism of the German speaker. A linguistic recognition of stereotype refers to the interdisciplinary character of this concept, so especially the history plays a major role in this description.
\end{abstract}

\section{Wstęp}

Niniejszy artykuł dotyczy obrazu języka niemieckiego utrwalonego w kulturze polskiej na przestrzeni wieków i jego weryfikacji przy pomocy ankiety przeprowadzonej wśród zielonogórskich studentów filologii germańskiej. Na wstępie należy jednak zaznaczyć, że szczególnie wśród lingwistów utarty jest pogląd, iż badanie ludzkich przekonań i nastawień do własnego języka jak i do języków innych osób czy grup jest na wskroś skomplikowane. Często padają bowiem w tym kontekście oceny i stosowane są kategorie, które zasługują na miano „lingwistycznie zabronionych" (zob. G. Stickel 2003: 3). Do tychże kategorii należą m.in. „piękno” i „brzydota” czy też stopień trudności danego systemu językowego.

Czynnikiem motywującym przeprowadzenie poniższych badań były analizy pani profesor Mariny Foschi Albert z Uniwersytetu w Pizie, która w czerwcu 2016 roku przeprowadziła wśród swoich włoskich studentów filologii germańskiej ankietę w języku włoskim dotyczącą obrazu języka niemieckiego we Włoszech (zob. M. Foschi Albert 2016). Zainspirowana wynikami włoskich badań przedstawiłam w marcu 2017 roku analogiczną ankietę w języku polskim studentom filologii germańskiej Uniwersytetu Zielonogórskiego, której wyniki są prezentowane w niniejszym artykule. 


\section{Stereotypy językowe}

Stereotypy na temat poszczególnych języków związane są nierozerwalnie z postrzeganiem i oceną jego użytkowników. Język niemiecki jest więc widziany w pierwszej linii przez pryzmat Niemca, tak jak język polski percypowany jest przez pryzmat Polaka. Dość obrazowo do istoty stereotypów narodowych nawiązuje niemieckie wydanie tygodnika „Newsweek” z roku 1990, w którym czytamy:

Im Himmel sind die Humoristen Briten, die Liebhaber Franzosen und die Mechaniker Deutsche. In der Hölle sind die Deutschen die Humoristen, die Briten die Liebhaber und die Franzosen die Mechaniker“, ',W niebie Brytyjczycy są komikami, kochankowie Francuzami, a Niemcy mechanikami. W piekle Niemcy to komicy, Brytyjczycy kochankowie, a Francuzi mechanicy' (zob. Newsweek 14.05.1990: 40, thum.: J. D.-B.).

Tego rodzaju zestawienia nie są charakterystyczne wyłącznie dla języka niemieckiego, lecz funkcjonują podobnie w wielu wspólnotach szczególnie w kontekście gatunku jakim jest żart, dowcip czy kawał. Powszechnie cytowany przykład stanowi historia o Francuzie, Angliku, Amerykaninie, Niemcu, Rosjaninie, Bułgarze i Polaku, którzy mają za zadanie napisać rozprawkę na temat słonia. Tekst Francuza nosi tytuł: „O erotycznym życiu słonia”, Anglik pisze „O słoniu w naszych koloniach”, Amerykanin pyta w tytule: „The elephants - how to make them bigger and better”, Niemiec skreśla dziesięciotomowy podręcznik: „Słoniologia: wprowadzenie do istoty słonia”, Rosjanin nadaje swej rozprawce tytuł: „Rosja - ojczyzną słonia”, Bułgar opatruje rozprawkę tytułem: „Słoń bułgarski - młodszym bratem rosyjskiego słonia”, natomiast tekst Polaka to: „Słoń a sprawa polska” (zob. J. Dąbrowska 1999: 37, por. też T. Torbus 1993: 17 i L. von Zitzewitz 1992: 82).

Językoznawcze ujęcie stereotypu odwołuje się do jego interdyscyplinarnego charakteru, a więc uwzględnienia badania z zakresu psychologii, antropologii, socjologii, historii etc. Stereotypy stanowią z lingwistycznego punktu widzenia elementy znaczeniowe, które możemy opisywać semantycznie i pragmatycznie. Elementy te mogą być różnorodnie wyrażane, a co za tym idzie również i rekonstruowane (por. J. Dąbrowska 1999: 85). Stereotypy są umiejscowione pierwotnie na płaszczyźnie mentalno-kognitywnej, a ich językowa realizacja odbywa się w konkretnych aktach językowych (por. J. Dąbrowska 1999: 85). Kilian pisze w tym kontekście o tzw. asocjacyjnych stereotypów semantycznych, przy których ważną rolę odgrywa kryterium konwencjonalności, wyrażające się przypisywaniem konkretnych wyrażeń do poszczególnych treści (por. J. Kilian 2015) i tak np. „typowy Duńczyk” jest opisywany przez niemieckich użytkowników języka jako „,blondyn”, „wysoki”, „opanowany”, ,przyjazny”, ,trunkowy” etc. (por. E. Hallsteinsdóttir 2016: 38).

\section{Stereotypy narodowe - charakter narodowy}

Zestawienia zaprezentowane powyżej chociażby przy opisie rozprawki na temat słonia nie są właściwością ostatnich lat, lecz istnieją od dawna. Atrakcyjnym przykładem stereotypizacji pochodzącej z początku XVIII wieku jest tzw. „tablica narodów". Stanowi ona graficzno-tekstowy przegląd atrybutów charakterystycznych dla różnych grup etnicznych. Ta najbardziej znana tablica pochodzi z Austrii, a dokład- 
nie mówiąc ze Styrii i jest datowana na lata 1730-1740. W anonimowym zestawieniu jawi się nam dumny i honorowy Hiszpan obok cierpiącego na syfilis Francuza. Polacy i Węgrzy to europejskie warchoły, Moskale czyli Rosjanie to złośliwcy kończący swój żywot w śniegu (por. F.K. Stanzel 1999: 41, por. F.K. Stanzel 1998).

Osiemnaście rubryk omawianej tabeli przedstawia dziesięć narodów, przy czym Greków i Turków ujęto wspólnie, ponieważ Grecja znajduje się wówczas pod turecką okupacją. Nie ulega wątpliwości, że takiego rodzaju wyliczenia są na wskroś powierzchowne i czysto fenomenologiczne. Przykład omawianej tablicy narodów ukazuje jednak dobitnie zbiorową charakterystykę różnych grup etnicznych i stanowi jedno z porównawczych źródeł w badaniach nad stereotypami.

„Niemiec" przedstawiony na tablicy narodów ze Styrii to osoba 'poczciwa' w swych obyczajach (offenherzig), tzn. 'otwarta' i 'szczera', jego natura i cechy charakteru opisywane są jako 'nad wyraz dobre' (ganz gut). W kolumnie 'rozum' (Verstand) znajdujemy adnotację (Wizig) 'mądry', który to przymiotnik w XVIII wieku nie oznacza tak jak dzisiaj w języku niemieckim człowieka 'dowcipnego', lecz takiego, który zachowuje się 'roztropnie' i 'rozważnie' (J. Grimm/ W. Grimm, 1960 t. 30: 891). Cechą charakterystyczną Niemca ma być to, że 'we wszystkim uczestniczy', czy też 'zawsze asystuje' (Über Allmit). Jeśli chodzi o naukę, to miłuje 'jurysprudencję' (In Weltlichen Rechte), w kwestii ubrania kieruje się modą innych, gdyż jak mówi wpis 'wszystko powtarza' (Macht alles Nach). Jego przywarą jest 'rozrzutność' i 'trwoniący tryb życia' (Verschwenderisch). Kocha 'pić' (Den Trunck), a chorobą narodową, na którą cierpi Niemiec jest podagra (An bodogrä). Grunty, które posiada są 'dobre' (Gut), a cnoty wojenne reasumuje uwaga 'nieprzezwyciężony' (Uniberwindlich). W kwestiach religijnych jest 'bardziej skupiony' i 'bardziej pobożny' (Noch Andächtiger) aniżeli Włoch, którego cechy opisywane są bezpośrednio przez charakterystykę Niemca. Przy pytaniu o władcę informacja brzmi, że czci 'cesarza' (Einen Kaiser). Pod dostatkiem posiada 'zboża' (An Getraid), a swój czas najchętniej spędza 'pijąc' (Mit Trincken). W świecie zwierząt Niemiec ma przypominać 'lwa' (Einen Löben), a swój żywot ma zakończyć pijąc 'wino' (In Wein).

Na tablicy ze Styrii stereotyp jawi się opisowo, choć często poszczególne rubryki nawiązują do siebie tak jak już to miało miejsce we wspomnianym przypadku religijności u Niemca i Włocha. Ciekawym udokumentowaniem takiego właśnie odnoszenia się do siebie sąsiadujących rubryk jest wpis dotyczący przywary Węgra, którą ma być 'zdradzieckość' (Veräther). Rosjanin w rubryce obok ma być jeszcze 'bardziej zdradziecki' (Gar Verätherisch) aniżeli Węgier, a 'jeszcze bardziej zdradzieccy' (noch Verätherischer) od Rosjanina mają być Grek i Turek. Zestawienia takie mają więc wielostronny charakter i często odnoszą się do siebie.

Stereotypy narodowe stanowią bez wątpienia stabilny składnik systemów wartościowania grup kulturowych i są przekazywane z pokolenia na pokolenie jako element skoncentrowanej wiedzy danego społeczeństwa. Amerykański socjolog Ehrlich podkreśla, że nie ma osoby, która wyrasta w społeczeństwie bez znajomości stereotypów przypisywanych najważniejszym grupom etnicznym (por. H. Ehrlich 1979: 47). W tym kontekście szczególną rolę odgrywa relacja między stereotypem, 
a dość drażliwą kategorią 'charakteru narodowego' (por. G. Prinz 1970: 199). Często zwraca się uwagę na to, że charakter narodowy jest kategorią nie dającą się bliżej opisać, z drugiej jednak strony wielu badaczy twierdzi, że termin ten sprawdza się najlepiej przy skrótowym „określaniu tożsamości narodów w ich długich procesach rozwojowych" (por. E. Lewandowski 1995: 10). Lewandowski uważa bowiem, że w tym względzie niezbędna jest jakaś kategoria teoretyczna, która będzie pozwalała na identyfikowanie się i porównywanie wspólnot etnicznych, a w konsekwencji tego będzie prowadziła do zrozumienia ich działań (por. E. Lewandowski 1995: 10).

Bez zgłębiania w tym miejscu teorii dotyczących powstawania narodów, należy jednak choć krótko nawiązać do ciekawych przemyśleń Balibara i Wallersteina (E. Balibar/ I. Wallerstein 1992) podkreślających, że narody nie są niczym naturalnym i dlatego też należy je postrzegać jako wspólnoty wyimaginowane, które powstały w efekcie działania instytucji. Naród nie istnieje więc sam z siebie, lecz tworzy się stale na nowo. W tym celu niezbędną okazuje się ideologia, która ma za zadanie wpłynąć na jego homogeniczność. Ponieważ jednak bardzo często jako naród definiowane są osoby, które nie posiadają ze sobą zbyt wielu podobieństw społecznych czy kulturowych, ustalenie ich tożsamości następuje w wyniku separacji jednej grupy od innych grup etnicznych.

\section{Autostereotyp versus heterostereotyp}

Ważnym aspektem stereotypizacji jest wzajemna relacja między auto- i heterostereotypem. Autostereotyp jest obrazem, który pewna grupa posiada sama o sobie, czyli tzw. samooceną. Natomiast heterostereotyp to percepcja obcego, wyobrażenie, jakie jedni mają na temat drugich. Autostereotyp żywi się stereotypem innych, a przede wszystkim obrazem najbliższych sąsiadów. $Z$ ową parą pojęciową wiążą się również niezmiennie dwa przeciwieństwa: sympatia dla grupy własnej i awersja dla grupy obcej.

Również w kontaktach polsko-niemieckich wzajemne relacje auto- i heterostereotypów odgrywają kluczową rolę. Lempp zwraca tu na przykład uwagę na ciekawą zależność, która kształtuje zachowania Polaków po dziś dzień, a dotyczy postulatu polskiego 'niezdyscyplinowania', który na zasadzie kontrastu do niemieckiego 'zdyscyplinowania' i dokładności' cieszył się w społeczeństwie polskim dużą popularnością w czasie rozbiorów kraju w XIX wieku (por. A. Lempp 1993: 15). Jednocześnie należy jednak podkreślić, że Polacy interpretują takie właśnie 'niezdyscyplinowanie' jako 'niepodporządkowywanie się władzy' i 'nie bycie małostkowym, nie bycie służbistą, który zbyt pedantycznie wykonuje wszelkie naka$\mathrm{zy}^{\prime}$, a które to określenia zarezerwowane są w kulturze polskiej do opisywania Niemców.

Tym samym więc zgoła inny system wartości kształtował się na przestrzeni wieków w obydwu społeczeństwach: polskim i niemieckim na zasadzie odseparowywania się od siebie. 


\section{Stosunki polsko-niemieckie na przestrzeni wieków}

W perspektywie historycznej stosunki polsko-niemieckie opisywane są często jako tysiącletnia nienawiść. Do dziś popularne w języku polskim przysłowie datowane na XVII wiek i czasy republiki szlacheckiej - Jak świat światem nie będzie Niemiec Polakowi bratem, podkreśla konfliktogenne relacje przedstawicieli obu wspólnot językowych. To popularne powiedzenie używane przede wszystkim w sytuacjach dnia codziennego unaocznia złe nastawienie obu narodów do siebie, a jego mówca sugeruje poniekąd, że za takowy stan rzeczy odpowiedzialny jest Niemiec (por. W. Wrzesiński 1994: 64).

Również samo określenie Niemiec nawiązuje do prasłowiańskiego niemówiący w domyśle 'po słowiańsku' i do przymiotnika niemy, według spostrzeżenia, że osoba tak definiowana nie mówi i nie rozumie mowy polskiej. Holzer podkreśla, że słowo Niemiec nie pozostawia żadnych wątpliwości odnośnie odczuć wyobcowania i niechęci, które towarzyszyły stosunkom polsko-niemieckim w czasie jego powstawania (por. J. Holzer 1991: 83).

Negatywne nastawienie Polaków do Niemców znajduje również wyraz w wyrażeniach, którymi określany jest zachodni sąsiad. Przykładem niech będzie chociażby pierwotnie obiektywna nazwa $s z w a b$, datowana na okres średniowiecznych kontaktów Polaków i Niemców na ziemiach polskich, kiedy ta nazwa wprawdzie nie zawsze odpowiadała rzeczywistości, ale z czasem stała się poniekąd popularnym wyzwiskiem na wszystkich Niemców.

Podobny do szwaba, negatywny charakter posiada również określenie krzyżak, sięgające wstecz do czasów niemieckiego Zakonu Krzyżowego. Wyrażenie to konotowano głównie z ekspansją, brutalnością i bezwzględną nienawiścią do polskości. W czasach nowożytnych Polacy określają Niemca jako Prusaka, która to nazwa jest identyczna z tą, w jaki sposób określa się owady: karalucha czy karaczana. Holzer podkreśla w tym kontekście, że niezależnie czy chodziło o Niemca, czy o owad wyraz ten wywoływał u Polaków podobne asocjacje (por. J. Holzer 1991: 83).

Jeśli jednak zagłębimy się w historię, możemy odnotować również i dłuższe okresy pokojowej koegzystencji Niemców i Polaków. Topolski zauważa (zob. J. Topolski 1993: 7), że ambiwalentne uczucia Polaków wobec Niemców obrazują doskonale już same tytuły prac zajmujących się stosunkami polsko-niemieckimi. I tak na przykład w roku 1945 ukazuje się książka Wojciechowskiego „Polska Niemcy. Dziesięć wieków zmagania” (zob. Z. Wojciechowski 1945), w roku 1987 wychodzi praca pod redakcją Czubińskiego „Polacy i Niemcy: dziesięć wieków sąsiedztwa" (zob. A. Czubiński 1987), a w roku 1992 Wrzesiński pyta w kontekście Niemca: „Sąsiad czy wróg?” (zob. W. Wrzesiński 1992). Przytoczone tytuły unaoczniają wyraźnie, że stosunki polsko-niemieckie w powojennej Polsce cechuje ambiwalencja i ich jednoznaczne zaszufladkowanie jest niemożliwe.

W Polsce powojennej socjalistyczny rząd propaguje głównie obraz niemieckiego agresora i faszysty. Grucza podkreśla, że język niemiecki w powojennej Polsce konotowany jest przede wszystkim z wyrażeniami jak raus! (wynocha), Hände hoch! (Ręce do góry!) czy pozdrowieniem Heil Hitler! (Niech żyje Hitler!), które z czasem zostaje przekształcone w sformułowanie Hitler kaputt! (wykończony / skończony 
Hitler!) (por. F. Grucza 1997: 28 cyt. za B. Sekulski 1998: 183).Taka znajomość języka niemieckiego znajduje olbrzymi rezonans w polskiej literaturze i kinematografii, wywierając niewiarygodny wpływ na powstawanie stereotypów dnia codziennego, gdy grupy dzieci bawiących się na podwórku dzielą się na dobrych, czyli Polaków i złych, czyli Niemców, posługujących się ową połowiczną niemczyzną.

Olga Tokarczuk pisze w kontekście owego powojennego postrzegania Niemców przez pryzmat konfrontacji zbrojnej, że wówczas Niemiec był wrogiem metafizycznym, działającym z oddali podstępnie i podle. Gdy bawiło się na zewnątrz w wojnę, nikt nie chciał być Niemcem. Byłoby to coś takiego jak przejście na drugą stronę mocy, jakby się to określiło w „Gwiezdnych wojnach” (por. O. Tokarczuk 2006: 24).

Polska kinematografia XXI wieku prezentuje jednak zgoła inny, uaktualniony obraz Niemca, który bazuje jednak mimo wszystko na stereotypowych wojennych etnonimach. Do wielu wyobrażeń o zachodnich sąsiadach, które są mocno zakorzenione w polskiej mentalności odwołuje się między innymi komedia "Wkręceni” Piotra Wereśniaka z roku 2013. Ukazany w niej „mityczny inwestor z Niemiec” traktowany jest przez Polaków niczym król w nadziei, że ulokuje swój kapitał w Polsce. Gdy jeden z bohaterów stwierdza: „Wzięli nas za Niemców!”, pada pytanie: „Za jakich Niemców?”, na które odpowiedź brzmi: „Wzięli nas za Szwabów, normalnych, hitlerowskich!” Konkluzja tego stwierdzenia to: „Ja nie chcę być Niemcem!"' (Wkręceni 2013).

Aspekty pragmatyczne komunikacji polsko-niemieckiej unaocznia fragment, w którym jeden $\mathrm{z}$ bohaterów thumaczy swym kolegom, w jaki sposób należy podszyć się pod Niemca, tak aby nie zostać zdemaskowanym jako Polak. Należy więc mówić: „z góry, oko, mina, postawa z góry na kmiotów” (Wkręceni 2013). Polski heterostereotyp Niemca prezentuje go jako bogatego przybysza z Zachodu, dlatego osobę lepszą, gdyż zamożniejszą od Polaka i dającą to odczuć nieśmiałemu mieszkańcowi polskiej prowincji.

Język niemiecki prezentowany w omawianej komedii jest na wskroś zminimalizowany i ogranicza się do ewidentnie przerysowanych sformułowań jak podziękowania: Danke, danke (Dziękuję, dziękuję), pożegnań typu: Tschüss! (Cześć!), Auf Wiedersehen! (Do widzenia!), formułek powitalnych: Guten Tag! (Dzień dobry!), potwierdzeń: ja, ja, ja (tak, tak, tak!), wyrażania pochwały: Service ist hohoho! (obsługa jest hohoho!), jak i do wyliczenia nazw kilku niemieckich produktów, takich jak Porsche, Mercedes czy Messerschmitt (Wkręceni 2013).

Dzisiejszy obraz Niemca kształtuje bez wątpienia również wspólne członkostwo w Unii Europejskiej, a tym samym poczucie wspólnoty wyrażające się w różnorodnych kontaktach między obywatelami wszystkich grup wiekowych i warstw społecznych. Owe kontakty odbywają się na wielu płaszczyznach, nie tylko politycznej i gospodarczej, ale również turystycznej, studenckiej czy zawodowej. Republika Federalna Niemiec ma opinię europejskiego silnika gospodarczego i wybór kierunku studiów „Filologia Germańska” nie jest już dziś komentowany tak, jak bywało to jeszcze czasami pod koniec lat 80-tych XX-wieku, gdy spotykałam się z uwagami, że studia germanistyki wybrano, ponieważ ,język wroga trzeba znać”. 
W kontekście tak korzystnych uwarunkowań powstaje naturalnie pytanie, czy negatywny obraz języka niemieckiego i samych Niemców jest dziś aktualny w świadomości młodych Polek i Polaków decydujących się na jego studiowanie.

\section{Ankieta wśród polskich studentów filologii germańskiej}

W marcu 2017 roku przeprowadziłam wśród studentów kierunku „Filologia Germańska" na Uniwersytecie Zielonogórskim ankietę w języku polskim dotyczącą postrzegania języka niemieckiego, jak i samych użytkowników tego języka. W ankiecie wzięło udział 78 osób. Analogiczna ankieta w języku włoskim została przeprowadzona przez Foschi Albert na Uniwersytecie w Pizie w czerwcu 2016 roku.

Wszystkie dane zostały podzielone na dwa bloki tematyczne. W pierwszej części respondenci określili swój wiek, płeć oraz ich osobisty stosunek do języka niemieckiego i do krajów niemieckojęzycznych. Studenci wypowiedzieli się również i ocenili sytuację ekonomiczną w krajach niemieckojęzycznych, porównali ją z Polską i odnieśli się do własnej sytuacji ekonomicznej.

W drugim bloku tematycznym wysondowane zostało nastawienie do języka niemieckiego jak i to, jakie cechy są jemu przypisywane.

\subsection{Respondenci i sytuacja ekonomiczna}

78 ankietowanych to osoby w przedziale wiekowym od 18 do 29 lat. Wśród nich większość, czyli 66 osób stanowią kobiety, a 12 osób to mężczyźni. 41 studentek to osoby znajdujące się na studiach pierwszego stopnia, tzw. studiach licencjackich, 25 studentek uczęszcza na studia drugiego stopnia (studia magisterskie). Wśród mężczyzn mamy analogicznie 9 osób na studiach pierwszego i 3 osoby na studiach drugiego stopnia.

Zdecydowana większość ankietowanych (99\%) ocenia swą znajomość języka niemieckiego jako przeciętna bądź zaawansowana. Tylko 1\% podaje, że jest w tym względzie nowicjuszem. 17\% respondentów przebywało powyżej trzech miesięcy w jednym z krajów niemieckojęzycznych. Najczęściej, w 47\% były to pobyty nie dtuższe aniżeli dwa tygodnie, a tylko 5\% nigdy nie wyjeżḋała do krajów niemieckojęzycznych.

$67 \%$ ocenia dzisiejszą sytuację polityczno-ekonomiczną w Niemczech jako dobra czy też bardzo dobra, natomiast tylko 9\% określa ją jako niezadowalająca bądź negatywna. Ekonomia i polityka Austrii i Szwajcarii postrzegane są jeszcze lepiej: $76 \%$ opisuje tamtejszy rozwój jako zadowalający bądź doskonały. Tylko jedna osoba określa go jako niezadowalajacy.

W przeciwieństwie do tej oceny, sytuacja polityczno-ekonomiczna Polski postrzegana jest przez większość - 51\% jako bardzo zła i zła, tylko 6\% określa ją jako dobra bądź bardzo dobrą. Tylko 4\% respondentów opisuje własną sytuację ekonomiczną jako pozytywną. Niezadowolonych z niej jest 35\% ankietowanych, a jako przeciętna określa ją 62\%. 96\% respondentów patrzy z nadzieją w przyszłość i oczekuje rychtego polepszenia się ich sytuacji. 


\subsection{Opinie o języku niemieckim i osobach niemieckojęzycznych}

W drugiej części ankiety studenci opisywali to, czy język niemiecki im się podoba. $54 \%$ ankietowanych podało, że język niemiecki podoba im się bardzo lub ogromnie. $37 \%$ stwierdziło, że dosyć się podoba, a odpowiedź nie za bardzo i w ogóle się nie podoba padła u $9 \%$ respondentów.

Następnie ankietowani mieli za zadanie ocenić język niemiecki przy pomocy pięciu przymiotników, które były zastosowane również przy badaniu studentów włoskich. Należały do nich określenia: melodyjny, logiczny, piękny, prosty i miękki W znaczeniu mity dla ucha. W oryginalnej włoskiej ankiecie przeprowadzonej przez Foschi Albert brzmia one melodiosa, logica, bella, dolce, facile (por. M. Foschi Albert 2016). W języku niemieckim, w którym autorka publikuje wyniki ankiety Foschi Albert posługuje się określeniami: melodisch, logisch, schön, einfach i weich (por. M. Foschi Albert 2017: 100).

Dla 63\% zielonogórskich studentów język niemiecki jest bardzo logiczny i logiczny, a tylko 4\% postrzega go jako nielogiczny. Bardzo zbliżone wyniki w tym przypadku prezentuje ankieta z Pizy, gdzie studenci postrzegają język niemiecki w 97\% jako język logiczny. Foschi Albert pisze w tym kontekście, że wynika to najprawdopodobniej z wiedzy ogólnej studentów, którzy kojarzą język niemiecki z filozofią Kanta czy Hegla (por. M. Foschi Albert 2017: 100). Czy polscy studenci germanistyki kierują się tą wiedzą, należałoby dopiero sprawdzić w następnych badaniach.

W oczy rzuca się również, że język niemiecki oceniany jest przez zielonogórskich studentów jako dość ładny - 62\%, a nawet piękny - 10\% natomiast brzydkim określa go 21\% respondentów. W przypadku badań przeprowadzonych przez Foschi Albert 78\% studentów ocenia język niemiecki jako piękny (schön) (por. M. Foschi Albert 2017: 100).

Pewnego rodzaju niepewność panuje natomiast przy ocenie brzmienia języka niemieckiego. Ankietowani w Zielonej Górze postrzegają go w 23\% jako melodyjny, $47 \%$ mówi o nim, że jest dość melodyjny, a dla 19\% jest on nieprzyjemny. W Pizie natomiast 53\% ankietowanych studentów ocenia język niemiecki jako nieprzyjemny (por. M. Foschi Albert 2017: 100). Również w przypadku zielonogórskich respondentów wypowiedzi odnośnie języka niemieckiego w kontekście cechy mity/miękki są najmniej pochlebne. Jako niemity i twardy oraz bardzo niemity i bardzo twardy określa go 44\%. Mity/miękki jest on tylko dla 8\% ankietowanych.

Bardzo podobne wyniki możemy zaobserwować w tym względzie u studentów włoskich, wśród których aż 61\% neguje miękkość języka niemieckiego odmawiając mu określenia miły dla ucha.

W odniesieniu do ostatniej cechy, a mianowicie trudności języka niemieckiego, to 54\% zielonogórskich ankietowanych uważa go za trudny, 31\% za dość łatwy, a tylko $6 \%$ za łatwy. Również i ten wynik koresponduje $\mathrm{z}$ danymi uzyskanymi w Pizie, gdzie aż 58\% studentów określiło język niemiecki jako trudny (por. M. Foschi Albert 2017: 100).

W końcowej części ankiety studenci mieli za zadanie scharakteryzować typowego mówcę języka niemieckiego przy pomocy trzech cech: sympatyczny, wykształco- 
ny i żywiołowy, w pięciostopniowej skali od bardzo sympatycznego do bardzo niesympatycznego, czy też od świetnie wyksztatconego do bardzo źle wyksztatconego. W oryginalnej włoskiej ankiecie przymiotniki te brzmiały: simpatico, educato, passionale (por. M. Foschi Albert 2016), a w niemieckiej prezentacji wyników badań: freundlich, gebildet, temperamentvoll (por. M. Foschi Albert 2017: 100).

Ankietowani zielonogórscy studenci wykazują największą 78\% aprobatę przy postrzeganiu Niemca jako osoby sympatycznej bądź też bardzo sympatycznej. Jako niezbyt sympatyczny jawi się on dla $13 \%$ ankietowanych, a $9 \%$ nie zabiera $\mathrm{w}$ tej kwestii zdania. Godnym uwagi jest również fakt, że nikt nie postrzega Niemca jako niesympatycznego bądź też bardzo niesympatycznego. Podobne, choć nie aż tak pozytywne oceny otrzymuje on we Włoszech, gdzie $66 \%$ widzi w nim osobę sympatyczna (por. M. Foschi Albert 2017: 100).

68\% ankietowanych w Zielonej Górze przypisuje Niemcowi atrybut wykształcony i bardzo wyksztatcony. Tylko 15\% respondentów postrzega Niemców jako niezbyt wykształconych. Odpowiedź źle wyksztatcony bądź bardzo źle wyksztatcony nie pada ani razu. W Pizie aż 78\% ankietowanych przypisuje Niemcom cechę wyksztatcony (por. M. Foschi Albert 2017: 100).

Jednocześnie 51\% zielonogórskich studentów widzi Niemców jako spokojnych i niezbyt żywiołowych. Wynik ten stanowi sporą różnicę względem włoskiej percepcji Niemców. Studenci w Pizie nie dopatrują się bowiem żywiołowości u Niemców aż w $91 \%$.

Ostatnie pytanie ankiety dotyczyło potencjalnych różnic między mieszkańcami poszczególnych regionów geograficznych Niemiec południowych, centralnych i północnych oraz Austrii i Szwajcarii. Wśród zielonogórskich ankietowanych 91\% odpowiedziało, że z pewnością one istnieją. Ocena ta różni się więc zdecydowanie od wyników włoskich, w których studenci z Pizy podali w ponad 50\%, że osoby niemieckojęzyczne nie różnią się między sobą i posiadają te same cechy niezależnie od tego czy mieszkają nad Morzem Północnym czy w Szwajcarii (por. M. Foschi Albert 2017: 100).

\section{Podsumowanie}

Ankieta przeprowadzona na Uniwersytecie Zielonogórskim wykazuje, że w świadomości młodych Polek i Polaków obraz Niemca, który był historycznie przekazywany z pokolenia na pokolenie, a w którym Niemiec jawi się jako agresor walczący z wszelkimi przejawami polskości ulega destrukcji. Zielonogórscy studenci filologii germańskiej postrzegają język niemiecki podobnie jak studenci z Pizy jako piękny i logiczny. Sami Niemcy określani są natomiast jako sympatyczni i dobrze wyksztatceni.

Kraje niemieckojęzyczne jawią się również obu wspólnotom językowym jako regiony gospodarczo rozwijające się i świetnie prosperujące, gdyż są postrzegane przez pryzmat mocnej gospodarki. Niewykluczone, że właśnie nadzieja na rozwój zawodowy w krajach niemieckojęzycznych stanowi ważny aspekt w heterostereotypie Niemca dla polskiego i włoskiego studenta germanistyki. 


\section{Bibliografia}

Balibar, E./ I. Wallerstein (1992), Rasse - Klasse - Nation: Ambivalente Identitäten. Wydanie 2. Hamburg/ Berlin.

Czubiński, A. (red.) (1987), Polacy i Niemcy: dziesięć wieków sasiedztwa. Studia ofiarowane profesorowi Januszowi Pajewskiemu w osiemdziesiata rocznicę urodzin. Warszawa.

Dąbrowska, J. (1999), Stereotype und ihr sprachlicher Ausdruck im Polenbild der deutschen Presse. Eine textlinguistische Untersuchung, (=Studien zur deutschen Sprache t. 17). Tübingen.

Ehrlich, H. J. (1979), Das Vorurteil. Eine sozialpsychologische Bestandsaufnahme der Lehrmeinungen amerikanischer Vorurteilsforschung. München.

Foschi Albert, M. (2016), Sondaggio d'opinione: Gli Italiani e la lingua Tedesca, (nieopublikowana ankieta),

Foschi Albert, M. (2017), Wie man in Italien über die deutsche Sprache dachteund wie man heute denkt, (w:) J. Dąbrowska-Burkhardt/ L.M. Eichinger/ U. Itakura (red.), Deutsch: lokal - regional - global. Tübingen, 89-102.

Grimm, J./ W. Grimm (1854-1971), Deutsches Wörterbuch in 33 Bänden, opracowany przez E. Wülcker/ R. Meiszner/ M. Leopold/ C. Wesle. (Przedruk pierwszego wydania 1999). Leipzig.

Grucza, F. (1997), „Vom Verhältnis der Polen zur deutschen Sprache“. Przedruk wykładu z corocznego zjazdu Instytutu Języka Niemieckiego w Mannheim, (w:) „Wirtschaft und Wissenschaft, Mitteilungsblatt des Stifterverbandes für die deutsche Wissenschaft" 2, 20-30.

Hallsteinsdóttir, E. (2016), Deutsch-dänische Nationalstereotype in der Sprache, (w:) E. Hallsteinsdóttir/ K. Geyer/ K. Gorbahn/ J. Kilian (red.), Perspektiven der Stereotypenforschung. Frankfurt a. M., 35-58.

Holzer, J. (1991), Der widerliche Schwabe, der brutale Preuße..., (w:) G. Trautmann (red.), Die hässlichen Deutschen? Deutschland im Spiegel der westlichen und östlichen Nachbarn. Darmstadt, 83-89.

Kilian, J. (2015), Von blonden Däninnen aus deutscher Sicht. Nationale Stereotype und didaktische Sprachkritik - ein Zwischenbericht aus einem laufenden Forschungsprojekt, (w:) C. Peschel/ K. Runschke (red.), Sprachvariation und Sprachreflexion in interkulturellen Kontexten. Frankfurt a. M., 155-182.

Lempp, A. (1993), West-östliche Bilder, (w:) Friedrich-Ebert-Stiftung (red.), Gesprächskreis Arbeit und Soziales 19, 11-26.

Lewandowski, E. (1995), Charakter narodowy Polaków i innych. Londyn/ Warszawa.

Prinz, G. (1970), Heterostereotype durch Massenkommunikation, (w:) „Publizistik“ $15,195-211$.

Sekulski, B. (1998), „Hände hoch, ich liebe dich!“ Stereotype Bilder im deutschen Minimalwortschatz. Ergebnisse eines deutsch-polnischen Projektes, (w:) M. Heinemann (red.), Sprachliche und soziale Stereotype. Frankfurt a. M., 155183. 
Stanzel, F.K. (1998), Europäer. Ein imagologischer Essay. Zweite, aktualisierte Auflage. Heidelberg.

Stanzel, F.K. (1999), Europäischer Völkerspiegel. Imagologisch-ethnographische Studien zu den Völkertafeln des frühen 18. Jahrhunderts, unter Mitwirkung von I. Weiler/ W. Zacharasiewicz. Heidelberg.

Stickel, G. (2003), Zur deutschen Sprache: die Innensicht der Außensicht (w:) G. Stickel (red.), Deutsch von außen. Institut für Deutsche Sprache Jahrbuch 2002. Berlin etc., 1-14.

Tokarczuk, O. (2006), Grüße aus Niederschlesien. Nach Jahrzehnten der Aufarbeitung ihrer Geschichte steht den Deutschen Trauer zu, die unversöhnliche Haltung der polnischen Regierung ist kindisch, (w:) „Frankfurter Rundschau“ z dnia 1.11.2006, 24-25.

Topolski, J. (1993), Rozwój stosunków polsko-niemieckich a problemy polskoniemieckoego pogranicza, (w:) K. Bartkiewicz (red.), Polacy-Niemcy. Idea dobrego sąsiedztwa. Rocznik Lubuski, t. 18. Zielona Góra, 7-22.

Torbus, T. (1993), Polen. Ein Reisebuch. Hamburg.

Wkręceni (2013): Film komediowy w reżyserii Piotra Wereśniaka. Produkcja: Tadeusz Lampka MTL Maxfilm.

Wojciechowski, Z. (1945), Polska - Niemcy. Dziesięć wieków zmagania, Poznań.

Wrzesiński, W. (1992), Sasiad czy wróg? Ze studiów nad ksztaltowaniem obrazu Niemca w Polsce w latach 1735-1939. Wrocław.

Wrzesiński, W. (1994), Nachbar oder Feind. Das Klischee des Deutschen in Polen im 19. und 20. Jahrhundert, (w:) F. Grucza (red.), Vorurteile zwischen Deutschen und Polen. Materialien des deutsch-polnischen wissenschaftlichen Symposiums 9. bis 11. Dezember 1992. Warschau.

Zitzewitz, L. von (1992), 5 mal Polen. Mit 17 Abbildungen u. 4 Karten. München. 